\title{
地球規模課題対応国際科学技術協カプログラム(SATREPS)
}

\section{研究課題別 終了時評価報告書}

\section{1. 研究課題名}

ベトナムにおける幹線交通網治いの斜面災害危険度評価技術の開発

(2012 年 4 月 2017 年 3 月)

\section{2. 研究代表者}

2. 1. 日本側研究代表者: 佐々 恭二（国際斜面災害研究機構 学術代表）

2. 2. 相手側研究代表者 : Nguyen Xuan Khang（交通科学技術研究所 (ITST) 所長)

\section{3. 研究概要}

ベトナム国は国土が南北に約 $1,700 \mathrm{~km}$ と長く、南北を貫く国道及び鉄道は同国の経済活動を 支える屋台骨であるが、地殼変動による脆弱な地盤や雨季の激しい降雨等によって斜面災害が 頻繁に発生し、時として経済活動の大きな妨げとなる。本プロジェクトでは、日本の先進的な 技術を基に、ベトナムにおける幹線交通網沿いの斜面災害を軽減するためのベトナムの自然 社会的条件に適した斜面災害危険度評価技術を共同開発する。また、当該技術の社会実装を可 能にするための人材が育成されることを目的とする。具体的には、以下の 4 つの研究題目を設 定し、サブ・グループを中心として研究を進める。

(1) 研究総括 · 教育 $\cdot$ 人材育成 (総括班)

（2）広域地すべりマッピングによる地すべり危険斜面の抽出（地形班）

（3）土質試験とシミュレーションに基づく斜面災害予測技術の開発（予測班）

（4）地すべり計測による危険度評価と早期警戒システムの構築（計測班）

\section{4. 評価結果}

\section{総合評価 （A：所期の計画と同等の取組みが行われ、成果が得られた。）}

地すべりによる幹線道路の被災は、ベトナムの経済発展を阻害する要因の一つであることか ら、幹線道路沿いの地すべり危険斜面を抽出し、且つ活動中の地すべり観測とそれに基づく地す ベり機構を明らかにする手法を開発し、相手国に技術移転することは意義がある。プロジェクト 開始当初の相手国体制の改編により、実験サイトの選定等に関して大きな変更を余儀なくされた が、その後の研究グループの努力により、最終的にはベトナム側研究者を主体とするガイドライ ンの完成まで至らしめ、社会実装への目処をつけた点は高く評価できる。特に、本研究で示され た衛星画像を活用して作成されたDSM（デジタル表層モデル）に基づいて地すべり地形を抽出す 
る手法は、今後アジアの熱帯多雨地帯での地すべり地形評価の有効な手法として活用されること が期待できる。

ベトナム側研究者が独自の地すべり危険度評価ガイドラインを作成した点は評価できるもの の、地すべりマッピング、土質試験とシミュレーション技術による災害予測、計測による危険度 評価と早期警戒技術システムの構築といった実サイトで実施した一連の作業から得られた知見 やノウハウ等の成果が、具体的にどのような形でガイドラインに反映されたかを十分に確認する ことができなかった。今後、ガイドラインの運用面で日本側研究者がフォローアップしていくこ とが望まれ、ガイドラインが政策に反映される機運があれば、さらなる継続的なバックアップが 必要である。

\section{4-1. 地球規模課題解決への貢献}

\section{【課題の重要性とプロジェクトの成果が課題解決に与える科学的・技術的インパクト】}

本プロジェクトでは、3 つのサブ・グループ（地形班、予測班、計測班）で課題に取り組み、 その成果の科学的・技術的インパクトは総じて高いと言える。

具体的には、地形班はベトナムの地形地質条件（特に強風化した岩盤斜面）に適応した地すべ り危険斜面の抽出・評価手法を開発したこと、且つALOS (陸域観測技術衛星)による全世界デジ タル 3D データ (DSM) から作成した地形図を用いて地すべり地形が判読できることを証明した。 後者の手法は、他の高温多雨地域においても有効に活用できることを提示した点で評価できる。

予測班はリングせん断機を改良して $100 \mathrm{~m}$ 深度相当の圧力下で試料の滑り実験を可能とし、深 層地すべりにも対応できることを示す等、地すべりの物理的性質の理解の向上、数値シミュレー ションへの取り込みに貢献した。

計測班は日本が持つ先端観測・計測技術をベトナムに技術移転し、その手法が有効であること を実証した点で評価できる。

\section{【国際社会における認知、活用の見通し】}

国際斜面災害研究機構（ICL）の活動を通じて、本プロジェクトの研究成果が国際社会におい て認知され、その手法の一部がそれぞれの国に適合し、活用される可能性が高い。また、国際的 な雑誌である Lands I ides に掲載された論文等で、国際社会において本研究課題の認知度を高め た努力は評価される。今後も、国際ジャーナルへの継続的な論文掲載を通して本研究の成果をさ らに活用されることが望まれる。

\section{【他国、他地域への波及】}

地形班は広域の地すべり地形マッピングを行い、強風化した岩盤斜面の地すべり地形の判読 · 図化と地すべりの再活動性の危険度評価を行った。周辺各国にも同様な地形・地質特性を有する 地域が広く分布することから、本評価手法は周辺各国に波及されることが十分に期待できる。土 
地利用が入り組んでいる森林を有する地域において、継続的に研究に活用されることも期待され る。

\section{【国内外の類似研究と比較したレベル】}

本プロジェクトは、平成 20 年度採択の SATREPS「クロアチア土砂・洪水災害軽減基本計画構 築」の発展的なものであり、きわめて独創的な研究手法が新たに開発されたとは言えず、地すべ り計測に関する研究としては標準的である。ただし、樹冠移動による地すべり前兆把握は実測デ 一タがやや不足しているものの、実用化の域に達しており、高い水準の研究と言える。衛星写真 から作成した DSM を用いて、熱帯地域の密林にて地すべり地形の判読が可能であることを示し た点も、新しいアプローチとして評価できる。

\section{4-2. 相手国ニーズの充足}

\section{【課題の重要性とプロジェクトの成果が相手国ニーズの充足に与えるインパクト】}

相手国の地形、地質は複雑で、熱帯性気候の影響を受けた岩盤風化による土砂災害に悩まされ ており、本プロジェクトの成果は相手国のニーズに十分応えるものである。当初計画にはなかっ たが、相手国の二ーズに応えて人工降雨斜面崩壊の実験を追加する等、相手国の関心と本研究の 目指すものとの折り合いの上でプロジェクトが推進されたこと、ベトナム側研究者が独自の地す ベり危険度評価ガイドラインを作成するに至ったことは評価できる。また、ハイバン峠は地すべ りに伴う災害ポテンシャルが高いにも関わらず、他国による支援は少なかった。その意味で、当 地において科学的プロジェクトを実施した価值は高い。

他方、相手国の行政事情により、本プロジェクトで得られた成果が同国交通省内のみの展開に 終わってしまう可能性は否めず、研究成果が相手国二ーズの充足に与えるインパクトを弱めてし まう懸念が残されている。

\section{【課題解決、社会実装の見通し】}

本プロジェクトの成果が総体として社会実装されることは考えにくいが、いくつかの卓越した 機器や手法が開発される等、社会実装への展望が開ける可能性は高い。具体的には、地形班が開 発した地すべり地形のマッピング、活動的な地すべり地における先端機器を用いたモニタリン グ、地すべり地の再活動性危険度評価等の手法が、本プロジェクトで作成された科学的根拠に裏 付けられたガイドラインに基づいて相手国の現場で活用される可能性が十分にある。

相手国内でガイドラインの活用について検討が進められていることについては評価できるも のの、ガイドラインの中身を現時点で十分に確認できないため内容に関する評価は難しい。 SATREPS の成果がガイドラインに反映されているか、そのガイドラインが実務レベルで有効に機 能し得るものか否かの確認が本来なされるべきである。 


\section{【継続的発展の見通し (人材育成、組織、機材の整備等)】}

本プロジェクトで実施した研修や我が国への留学を通じて若手研究者が相当数育成され、ITST の能力はかなり向上したものと思われる。日本での博士号取得者も輩出しており、こうした人材 がベトナム全土の地すべり災害軽減の中核になる可能性は十分にある。ベトナム側研究者が主体 的に地すべり危険度評価ガイドラインを作成したことは、人材育成がある程度なされたことを示 しており評価できる。ただし、ガイドラインが今後どのように社会実装され、活用されるのか見 通しが十分ではないため、日本側研究者が運用面でフォローアップする必要がある。

本プロジェクトで設置した機材については、故障等に対する対策が十分ではない点が散見され る。予測班及び計測班が開発あるいは設置した機材は先端的ではあるものの、高額なものとなっ ており、相手国の体制がこれらの機材を維持管理しながら継続して用いることができるのか不安 が残る。

【成果を基とした研究 - 利用活動が持続的に発展していく見込み（政策等への反映、成果物の利 用など)】

ベトナム側研究者が主体的に作成した地すべり危険度評価ガイドラインを交通省が全面的に 採用するのか現時点では不透明ではあるが、実際に採用されればベトナム国内の地すべり対策に 活用され、持続的な発展が期待できる。本プロジェクトによる提言、ガイドラインを政策に反映 させていくためには、継続したバックアップが必要不可欠である。

\section{4-3. 付随的成果}

\section{【日本政府、社会、産業への貢献】}

我が国のコンサルタント会社が、ODA 以外のルートで海外進出を果たすのは難しい。本プロジ エクトに関連した部門に継続して関わることを機に、中小規模のコンサルタント会社がベトナム に進出する契機とすることが期待でき、日本の産業への貢献はきわめて大きい。

日本の地すべり調査業務は、必ずしも本研究で行われたような高度なモニタリングや実験結果 に基づいて対策・立案が行われている訳ではない。甚大な地すべり災害が想定される地すべり地 に対して、本研究のような手法を導入すれば、我が国の土砂災害の減災にも有効であろう。

本プロジェクトの実施によって、日本の地すべり観測技術が現地で適応されることが実証され た。再活動の可能性が高いと判断された地すべり地やハイバン峠の観測地において、地すべり変 動が認められ、早期警戒に繋がれば、日本の防災技術のプレゼンスが高くなると考えられること から、今回実施された技術移転がベトナム側の自助努力で継続実施され、本プロジェクトで開発 した観測システムが本研究の調査地以外でも導入されることが望まれる。

\section{【科学技術の発展】}

本研究で開発された地すべり監視技術、地すべりシミュレーションはいずれも最先端の手法で 
あり、リングせん断機の改良、UAV-PIV 解析（UAV で撮影した地形を画像処理する手法の一種） や UAV 撮影写真から作成した DSM を用いた標高比較による地すべり変動の検出等、我が国の科 学技術の発展に寄与したと言える。地すべりマッピング策定のための技術開発、既存技術の組み 合わせと実装、土質試験に関する技術開発に積極的に取り組んでおり、企業や研究者によって今 後採用される可能性のある技術が開発されたことは評価できる。

\section{【世界で活躍できる日本人人材の育成（若手、グローバル化対応)】}

本プロジェクトでは一部の分野を除き、大学が中心的役割を果たした訳ではなく、主要メンバ 一が大学以外の研究機関に所属していることもあり、若手人材の育成という点では大きな成果が 得られたとは言えない。学生も含めて、日本人若手研究者による国際誌論文が一本もないのはき わめて寂しい。

【知財の獲得や、国際標準化の推進、生物資源へのアクセスや、データの入手】

知財の獲得は特に行われておらず、地すべり発生状況がそれぞれの地域の地質や地形、気候な どに大きく左右されることもあり、国際標準化にはなじまない。ただし、本プロジェクトで開発 された機器に関しては、今後のアピールの仕方によっては国際的にも様々な場所で利用されるこ とが考えられる。その実現のためには、今後も継続的な普及活動が必要である。

【その他の具体的成果物（提言書、論文、プログラム、試作品、マニュアル、データなど）】

国際誌に掲載されてはいるものの、成果発表の多くが Proceedings としてなされているため、 学術論文として成果を公表することを検討すべきである。LandsIides 誌上で複数の論文が発表 されているが、プロジェクトの規模の割には少ない。

\section{【技術および人的ネットワークの構築（相手国を含む)】}

ベトナムは縱割り行政がきわめて堅固な国であるため、移転された技術の共有が ITST 内のみ で行われる危惧はあるが、本プロジェクトを通じて「交通のためのベトナム地すべり学会」が設 立されたこともあり、ベトナム国側における省庁間を越えた人的ネットワークの構築が期待でき る。また、クロアチア課題からの人的ネットワークが継続・拡大しており、ICL を通じた国際的 ネットワークが確立されている。

\section{4-4. プロジェクトの運営}

\section{【プロジェクト推進体制の構築（他のプロジェクト、機関などとの連携も含む)】}

一般的に縱割り行政では、一旦ある組織が携わると他組織の介入が難しくなる。本プロジェク トは、相手国側の要請により交通省及びその傘下である ITST を共同研究機関として、研究対象 地域を幹線交通網沿いとしているが、社会実装面では農業農村開発省や天然資源環境省、研究面 
では大学を巻き込むことができれば研究成果の展開にも広がりがあったのではないか。また、相 手国の事情ではあるが、プロジェクト発足時に相手側研究機関及び上位機関の責任者の交代があ り、プロジェクト推進体制を確立するまでに時間を要し、十分機能することができなかった。開 始当初から関係組織をより積極的に巻き込んでいれば、よりスムーズなプロジェクト運営が行え たことが予想される。

一方で、プロジェクト初期に大幅な遅延が生じたが、困難な状況に直面しても科学的探究目標 を摇るがさずにプロジェクト運営がなされた。さらに、プロジェクト期間を通じて、ICL の活動 の周知や地すべりに関する各種シンポジウム等で他のプロジェクトや研究機関との連携を模索 する努力がなされたことは評価できる。

\section{【プロジェクト管理および状況変化への対処（研究チームの体制·遂行状況や研究代表者のリー ダーシップ)】}

研究代表者はプロジェクト推進実績を豊富に有しており、その強烈なリーダーシップによっ て、難しい状況の変化にも研究チームが素早く対応できた。多くの制約と予期せぬ相手国機関の 体制変化の中で、プロジェクトの成果を計画期間内に評価可能な状況まで到達させた手腕は評価 できる。その反面、サブリーダーの自主性発揮の機会がやや薄れた。

\section{【成果の活用に向けた活動】}

本プロジェクトでは研究と行政への社会実装のバランスが取れており、掲載数は多くはないが 国際的な雑誌である Lands I idesに掲載された論文を通じて成果を公表した点は評価できる。

33 編からなるガイドラインは完成したものの、交通省に提出した後の相手国側の活動状況が 十分に把握できていない。実際の防災対策として事業化されるまで、ベトナム側研究者の今後の さらなる努力が必要である。ベトナムの事情を考慮した場合、ガイドラインに SATREPS の成果が 随所に反映されていない可能性もあり、フォローアップが必要である。

\section{【情報発信（論文、講演、シンポジウム、セミナー、マスメディアなど）】}

国際シンポジウム等を通した情報発信が活発に行われており、国際的知名度は高い。相手国側 の政府要人の交代や、それに伴う要求の変化にも関わらず、一定の情報発信が行われており、そ の点では評価できる。

一方で、相手国での情報発信については、縦割り行政の影響もあり、広く相手国内にアピール するところまで達していない。本プロジェクトで設立された「交通のためのベトナム地すべり学 会」を通じて、本プロジェクトの成果が今後広く共有されることが期待される。成果の共有に際 しては、どの研究題目によってもたらされた成果であるかを整理して広報することが望まれる。 公表論文については Proceedings が多く、国際的な学術誌に本プロジェクトで得られた成果を 公表する努力が望まれる。 


\section{【人材、機材、予算の活用 (効率、効果)】}

本プロジェクトでいくつかの卓越した機器が開発されており、その点については評価できる。 観測機材は現在も稼動しており、研究成果の醸成に貢献したが、プロジェクト最終段階に一部の 機材の故障が発生する等のトラブルが生じた。今後の資機材の維持活用については、相手国研究 者の予算獲得の努力が必要であるとともに、相手国が継続して活用できるように日本側からも働 きかけを続ける必要がある。

\section{5. 今後の研究に向けての要改善点および要望事項}

- 本課題の大きな成果の一つである樹冠移動による地すべり抽出のうち、鉛直方向の変位測 定に関しては、熱帯のような樹木の生長が早い地域では場所によって生長量が大きく異な るので、樹木種と場所による影響の検討が必須である。水平方向の変位測定に関しても、形 態的に直立する適した樹木種を選択する等の仕組みが必要であろう。また、樹木の根の張り 方等も大きく影響するため、こうした検討は研究が進んでいる他分野で得られた知見を導 入することも一案である。

・地形班は広域の地すべり地形マッピングを行ったが、その基図に日本の技術である全世界 デジタル 3D 地図 (AW3D) $5 \mathrm{~m}$ 解像度の数值標高モデル (DEM) を用いた。最近は精度のより 高い AW3D (0.5 2m 精度) も入手できるようになっており、こうした地形データを用いれ ば、精度のより高い地すべり地形マッピングが可能であろう。

・ ハイバン地区では多種の地すべり計測器（長スパン伸縮計、通常の伸縮計、孔内設置型の鉛 直伸縮計、全地球航法衛星システム (GNSS)、トータルステーション、挿入型傾斜計、固定 式孔内傾斜計、間隙水圧水計、雨量計など）を同一の地すべり危険地に設置した。その目的 の一つに、「豪雨・多湿なベトナム他の国各々において計測器の精度、限界、耐久性および 現地への適用性等について検討すること」とあるが、それに対する検討結果が不明であり、 ガイドラインにどのように反映されているのか明らかにする必要がある。

以上 


\begin{tabular}{|c|c|}
\hline $\begin{array}{l}\text { 研究課題 } \\
\text { 名 }\end{array}$ & $\begin{array}{l}\text { ヘトナナムにおけける幹線交通網沿いの斜面 } \\
\text { 災害危険度評価技䢞の開発 }\end{array}$ \\
\hline $\begin{array}{l}\text { 研究代表 } \\
\text { 者名 (所属 } \\
\text { 枚関) }\end{array}$ & 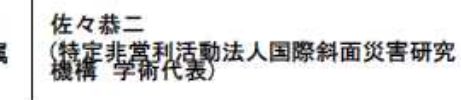 \\
\hline 研究期問 & $\begin{array}{l}\mathrm{H} 23 \text { 採択 } \\
\text { (平成23年 } 6 \text { 月 } 1 \text { 日 平成 } 29 \text { 年 } 3 \text { 月 } 31 \text { 日) }\end{array}$ \\
\hline $\begin{array}{l}\text { 相手国名 } \\
\text { 主要相手 } \\
\text { 国研究機 }\end{array}$ & 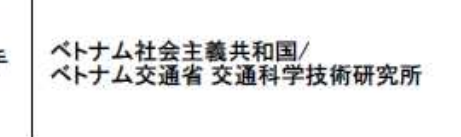 \\
\hline \multicolumn{2}{|r|}{ 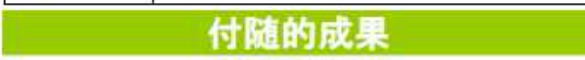 } \\
\hline $\begin{array}{l}\text { 日本政府、社 } \\
\text { 会、廉莱一の } \\
\text { 专献 }\end{array}$ & 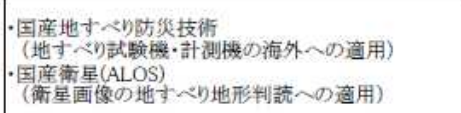 \\
\hline 科学技術 & 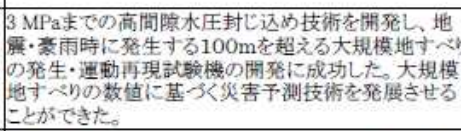 \\
\hline 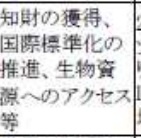 & 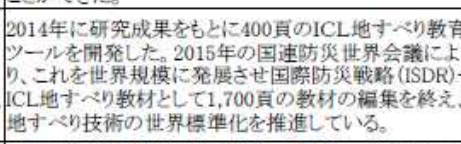 \\
\hline 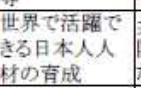 & 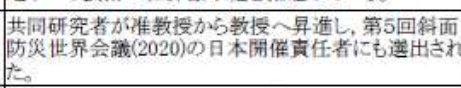 \\
\hline 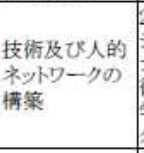 & 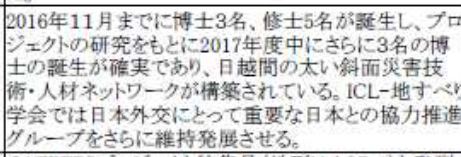 \\
\hline 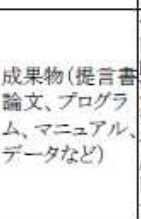 & 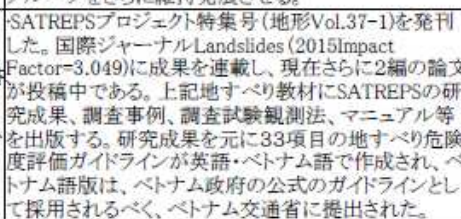 \\
\hline
\end{tabular}

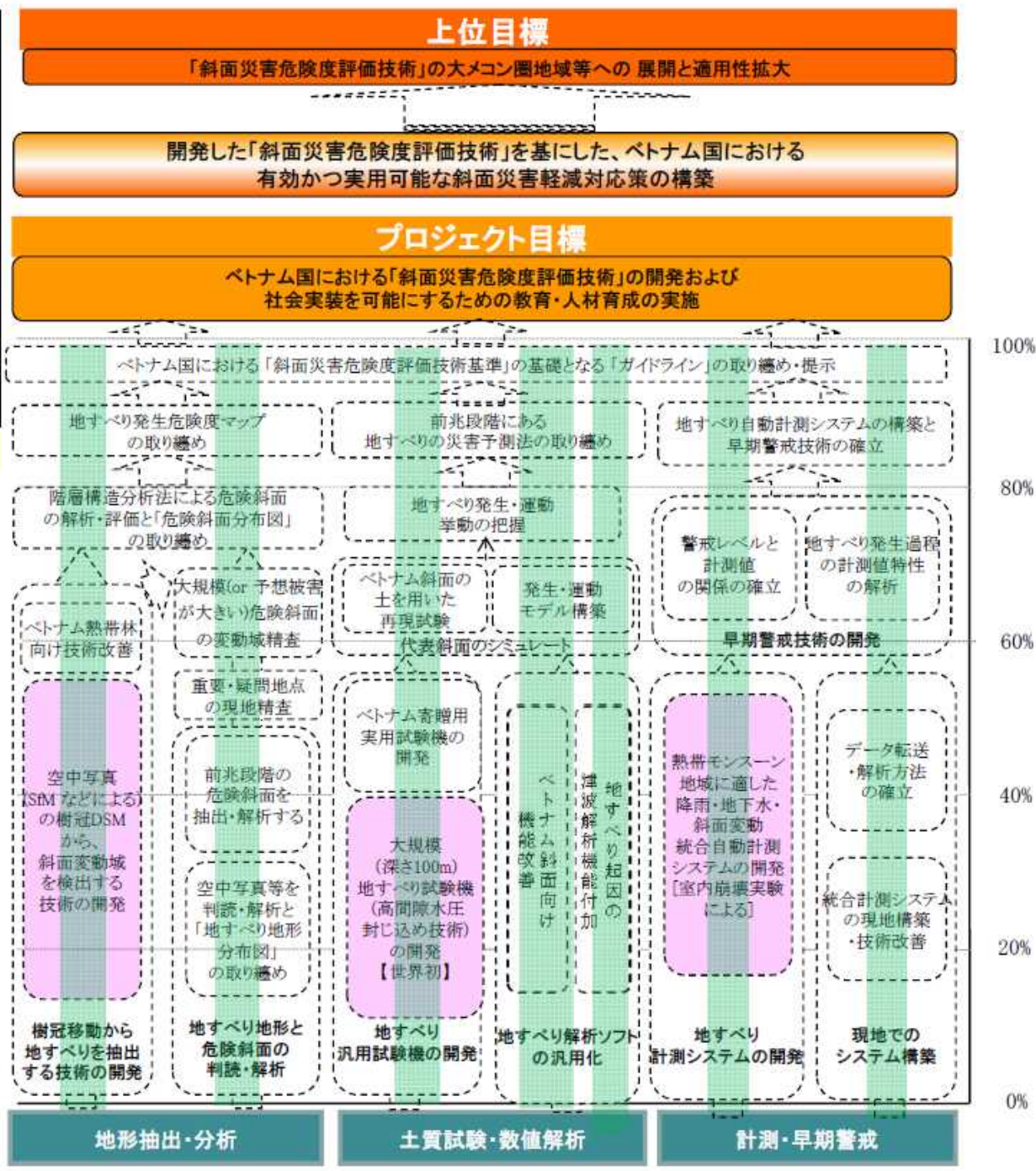

図 1 成果目標シ一トと達成状況（2016 年 12 月時点） 